\title{
CALVIN DAN SPIRITUALITAS KERAHIMAN
}

\author{
Stella Yessy Exlentya Pattipeilohy ${ }^{*}$
}

\begin{abstract}
"No other way to enter into life unless this mother conceive us in her womb." ('Tidak ada jalan masuk ke dalam kehidupan kalau kita tidak dikandung di dalamnya.') John Calvin ${ }^{1}$
\end{abstract}

\begin{abstract}
The keyword commonly used in mysticism and spirituality is "experience". The instilling of God's mercy, in fact, is a spiritual experience accosted by God's love. Such experience is shared in a transformative praxis. The mercy of God is a faith experience that could be made a meeting point in fostering a love-based religious life. In the Protestant tradition, we can find a foothold for the development of spiritual theology on John Calvin's work, i.e. the so-called merciful spirituality. Today's experience of God's mercy is influenced by the contextual concern about the image of the Homeless Jesus. The refugees not only "challenge" Christian communities to recognize the Christ within the needy strangers, but also welcome them in love and peace despite religious faith differences.
\end{abstract}

Keywords: experience, spirituality, mercy, Calvin, church as the mother, un-will people.

\begin{abstract}
Abstrak
Kata kunci yang umum digunakan dalam dunia mistik atau spiritualitas adalah "pengalaman" (experience). Penghayatan akan kerahiman Allah sesungguhnya adalah pengalaman spiritual disapa oleh cinta kasih Allah. Pengalaman ini berlanjut dalam tindakan
\end{abstract}

* Pendeta GPIB. Email: exlentyapattipeilohy@yahoo.com 
mencinta dan dibagikan bagi sesama dalam praksis transformatif. Allah yang merahimi menjadi pengalaman iman yang dapat dijadikan titik temu dalam mengembangkan hidup beragama yang dasarnya adalah cinta kasih. Di dalam tradisi Protestan dapat ditemukan pijakan mengembangkan teologi spiritualitas Protestan, yaitu pada spiritualitas John Calvin yang disebut spiritualitas kerahiman. Pengalaman akan kerahiman Allah di masa kini ditantang oleh keprihatinan kontekstual dalam gambaran Homeless Jesus. Pengungsi tidak hanya "menantang" umat Kristiani untuk mengenali Kristus dalam diri orang asing dan membutuhkan, tetapi juga menyambutnya dalam kasih dan damai sekalipun mereka berbeda agama atau keyakinan.

Kata-kata kunci: pengalaman, spiritualitas, kerahiman, Calvin, gereja sebagai ibu, un-will people.

\section{PENDAHULUAN}

Dalam dunia spiritualitas atau mistik, kata kunci yang umum digunakan adalah "pengalaman" (experience) (Sheldrake, 1998: 21; Knitter, 2002: 112-113, 125; Rice, 1991: 26; Johnston, 1987: 25; Dyckman dan Carroll, 1981: 79-80). Yang dialami adalah Allah yang mencintai. Merasakan cinta Allah atau disebut juga sapaan kerahiman-Nya adalah sebuah pengalaman. Penghayatan akan kerahiman Allah sesungguhnya adalah pengalaman spiritual disapa oleh cinta kasih Allah. Pengalaman berjumpa dengan Allah, pengalaman dicintai serta mencintai Allah. Dan pengalaman puncak akan cinta Allah sebagai yang menentukan dalam hidup beriman Kristiani ini tidak berhenti di situ. Pengalaman ini berlanjut dalam tindakan mencinta dan dibagikan bagi sesama.

Allah yang merahimi menjadi pengalaman iman yang dapat dijadikan titik temu dalam mengembangkan hidup beragama yang dasarnya adalah cinta kasih (Soetapa dalam Simon, 2013: 20-25). Karena itu, sangat menarik bila pada setiap tradisi agama-agama dicari dan ditemukan pengalaman kerahiman Allah itu untuk membangun jembatan berteologi agama-agama yang dasarnya adalah cinta dan belarasa sebagai isi dari kerahiman.

Dari tradisi Katolik, tahun 2016 ini disebut tahun Yubelium Agung Kerahiman Ilahi. Seperti diakui bahwa ini semacam "penemuan kembali” (rediscovery), setelah 35 tahun (1980) ensiklik Dives in Miserecordia ('Kaya dengan Kerahiman') dari Paus Yohanes Paulus II tidak tumbuh subur di dalam gereja, malah sudah dilupakan (Leks, 2016: 7-8). Untuk membawa kembali umat 
pada jantung Injil, Paus Fransiscus mengeluarkan Bulla Misericordiae Vultus yang dalam bahasa Indonesia diterjemahkan menjadi ‘Wajah Kerahiman' (Fransiscus, 2016; Pabubung, 2016: 35-37). Bulla atau surat resmi ini dibuka pada 8 Desember 2015 dan nanti ditutup pada 20 November 2016. Dalam bahasa Latin, kata Misericordiae ini berasal dari kata miserere yang berarti 'berbelas kasih', dan cor yang berarti ‘budi, hati, batin, jiwa'. Dengan kata lain, cor menunjuk pada peranan inti yang dimilikinya dalam hidup manusia. Maka, wajah kerahiman merupakan keseluruhan aspek dalam diri manusia dengan segala ketulusannya untuk menunjukkan belas kasih. Tahun kerahiman pertama-tama mengungkap kedalaman pribadi manusia yang tersapa oleh kerahiman atau belas kasih Allah dan menampakkannya dalam tindakan nyata berbelas kasih kepada orang lain dengan tanpa mengenal batas.

Pertanyaannya adalah adakah tema kerahiman di dalam tradisi Protestan yang dapat dijadikan pijakan mengembangkan teologi spiritualitas Protestan? Tulisan ini bermaksud menggali spiritualitas John Calvin (1509-1564) yang disebut spiritualitas kerahiman (Calvin, 2006: IV, 1016). Di sini saya berbeda dengan Th. van den End yang mengatakan bahwa: "Calvin bukan seorang spiritualis, atau seorang mistikus, yang mencari Allah dalam batin sendiri sehingga pada hakikatnya dalam hal agama ia tidak memerlukan persekutuan dengan sesamanya manusia" (van den End dalam Batlajery dan van den End, 2014: 140). Pandangan van den End ini mungkin harus diletakkan dalam porsi Calvin yang yuridis formal sebagai ahli hukum. Dalam konteks ini, van den End mewakili salah satu dari dua segi wajah Calvin yang dogmatis-legalistik. Pandangan Gerrit Singgih yang mengatakan Calvin adalah seorang yang intoleran (terutama skandal Michael Servetus yang dibakar hidup-hidup atas persetujuan Calvin tahun 1553) (Calvin, 1957: 218; Singgih, 2000: 52-56; Hartono, 1997: 465-478 [475]), mungkin juga harus diletakkan dalam konteks wajah Calvin yang legalistik ini. Namun, tulisan Agustinus Batlajery yang mendudukkan ulang tuduhan terhadap Calvin berada di belakang pembunuhan Servetus menjadi penting. Katanya:

"Jadi jelas bahwa ada usaha-usaha Calvin untuk menyelamatkan Servetus. Ia bekerja demi pengampunan Servetus [...] Ia tidak terlibat di dalam proses membuat keputusan, dan posisinya di Jenewa pada waktu itu sangat lemah. Sangat berbeda, ketika keputusan untuk 'pembakaran keji' itu dibuat ia mencoba bertanya dengan mengomunikasikan kalimat sebagaimana ia tunjukkan dalam sebuah surat yang ia tulis kepada Farel [...] Dan tentulah kita juga setuju bahwa kasus ini adalah sebuah kasus kekerasan. Tetapi kita tidak mengatakan bahwa ide tentang pembakaran yang keji ini datangnya dari Calvin.”1

Penjelasan ini cukup menggambarkan bahwa Calvin adalah seorang yang toleran. Bahkan edisi pertama Institutio dengan tegas mengatakan bahwa pembunuhan atas kaum bidah sebagai tindakan kriminal (Batlajery, 2014: 26, c.k. 6). Demi prinsip-prinsip kemanusiaan, Calvin bermaksud mengakhiri penggunaan api dan pedang dalam menyelesaikan masalah termasuk atas kasus Servetus. 
Selain penggambaran atas wajah yang pertama, ada wajah lain Calvin yang dapat diusut pada uraian bukunya Institutio yang dimulai dengan bagaimana Allah dapat dikenal manusia. Di sini mengenal (knowledge) sama dengan mengalami (experience) Allah (Rice, 1991: 25-27). Lebih jauh, mengenal Allah adalah mengenal diri sendiri dan mengenal diri sendiri adalah mengenal Allah. Bahkan Allah yang misteri dikenal melalui mengenal diri sendiri. Dari sinilah wajah spiritualis Calvin ditemukan. Sehingga, ketimbang mengikuti van den End, menurut saya Calvin termasuk seorang spiritualis, minimal pemikiran-pemikirannya mempunyai jejak sebagai seorang spiritualis.

Jejak spiritualitas Calvin ini pun sangat kuat dirasakan dalam Institutio yang merupakan karya utamanya sebagai seorang teolog reformasi. ${ }^{2}$ Institutio adalah ungkapan dari subita conversio (pertobatan tiba-tiba, mendadak, tidak direncanakan) Calvin atas pekerjaan Allah dalam hidupnya (Elwood, 2002: 10). ${ }^{3}$ Hakikat dari maksud pertama ditulisnya Institutio adalah menjadi buku pengajaran iman Kristen (katekismus), bukan buku dogmatika; bersifat lebih praktis daripada formal atau filosofis (Battles, 1996: 91-93). Institutio menjauhkan wajah legalistik-rasionalistik Calvin sebagai seorang ahli hukum yang legalistik apalagi intoleran, menjadi berwajah teolog spiritualis yang menghayati iman dalam pengalaman (experience) melalui "mengenal" (knowledge) Allah dan diwujudkan dalam "kesalehan" (pietas) (Rice, 1991: 25-27). Karena itu topik kerahiman yang diangkat dalam tulisan ini sangat khas dalam teologi Calvin sendiri. Kerahiman adalah belas kasihan itu sendiri. Itulah Allah yang kasih-Nya tidak mengenal batas. Merahimi adalah aktivitas intim dan emotif tanpa batas dari seorang ibu untuk memberi cinta dan mempertahankan kehidupan anak-anaknya sejak dari kandungannya sendiri. Dan spiritualitas ini terhubung kuat dengan apa yang Calvin katakan bahwa gereja adalah ibu yang merahimi hingga melahirkan kehidupan baru dan menyusuinya untuk memberi hidup bagi anak-anaknya.

\section{SPIRITUALITAS CINTA DALAM TRADISI KRISTIANI}

Kerahiman tidak terpisah dari cinta. Rahim itu sendiri adalah simbol dari cinta. Ketika mengatakan "being in love", ${ }_{4}$ Bernard Lonergan bermaksud menandai bahwa apabila Allah yang mengatasi segala-galanya adalah kekasihku, Dia sungguh berada dalam hatiku, Dia sungguh-sungguh nyata dari dalam diriku. Berada dalam cinta dengan Allah itu bersifat radikal karena merupakan penyerahan diri dan benar-benar total. Berada dalam cinta dengan Allah bersifat tanpa batas (limits) atau kualifikasi (qualification), tanpa persyaratan (conditions), dan tanpa ada yang ditahan 
(reservations). Ketika orang jatuh cinta (fall in love) kemampuan untuk transendensi diri seseorang menjadi aktual. Kemudian orang mencintai dan berada dalam cinta (being in love). Sekali cinta itu berkembang dan lestari, cinta itu akan menguasai. Dari cinta itu mengalir berbagai hasrat, kekuatiran, sukacita dan dukacita, penegasan dan pilihan nilai, keputusan dan tindakan (Lonergan, 1975: 105-106; Johnston, 2001: 83).

Sejalan dengan Lonergan yang menyebut "being in love with God" sebagai transendensi diri, William Johnston memahami ungkapan yang sama itu dengan cinta mistik sebagai tujuan dari kehidupan manusia. Cinta mistik itu merupakan titik puncak dari daya dorong menuju transendensi diri dan keautentikan yang berakar dalam akal budi dan hati semua makhluk manusia. ${ }^{5}$ Rupanya Lonergan dan Johnson memaksudkan mistik cinta sebagai keseluruhan, termasuk wujudnya dalam tindakan-tindakan dalam dunia nyata. Bahwa nyala mistik cinta itu benar-benar membakar hidup manusia dan membawanya dalam tindakan cinta secara nyata.

Dalam pengalaman Calvin, dorongan menuju transendensi diri dan keautentikan juga berdasar pada pengalaman akan cinta Allah. Sebuah "pertobatan tiba-tiba" (a sudden conversion) dalam merespon cinta Allah (Elwood, 2002: 10). Pengalaman dicintai Allah dan mencintai-Nya itu melahirkan "kesalehan" (piety). Dalam terjemahan Institutio berbahasa Inggris secara jelas digunakan kata pietas (piety) sebanyak dua kali, sehingga judulnya yang panjang berbunyi: "The Institute of the Christian Religion, Containing almost the Whole Sum of Piety and Whatever It is Necessary to Know in the Doctrine of Salvation. A Work Very Well Worth Reading by All Persons Zealous for Piety" (Calvin, 2006: xxxiii). Kesalehan (pietas) yang demikian diwujudkan dalam kerajinan beribadah, berdoa, dan keaktifan dalam berbuat kebajikan demi pengudusan hidup di dunia ini. Kata Calvin, "Saya namakan kesalehan ialah rasa hormat yang disertai rasa cinta kepada Allah. Pengetahuan itu dibangkitkan oleh kesadaran akan kebaikan-kebaikan-Nya terhadap kita." Perasaan cinta kepada Allah ini secara primordial terhubung dengan apa yang Calvin katakan tentang "kesadaran ketuhanan" (sensus divinitatis) sebagai perasaan atau kesadaran yang kuat akan kehadiran Allah, yang bersifat given pada setiap manusia. Katanya:

\footnotetext{
"Kita anggap sebagai suatu hal yang sudah tak dapat disanggah lagi bahwa manusia menyimpan dalam hatinya suatu kesadaran akan adanya suatu Allah. Hal ini malahan merupakan gerak hati yang wajar. Sebab, supaya tidak ada yang berdalih tidak tahu, Allah telah menempatkan dalam hati kita semua suatu pengetahuan akan diri-Nya, dan pengetahuan itu sewaktu-waktu dihidupkan-Nya kembali dalam ingatan kita."7
}

Itu berarti bahwa pengalaman cinta Allah yang berkobar-kobar itu adalah sesuatu yang melekat dalam setiap orang dan melahirkan kesalehan (pietas) sebagai sikap hormat kepada Allah di dalam kebajikan dan tindakan etis yang nyata. 
Menurut Janet Ruffing, "Tradisi Kristiani tentang mistik cinta didasarkan dalam tradisi Alkitab, yakni pribadi Allah yang menyatakan cinta yang memberikan Yesus." Mediasi Yesus lalu memberi pengalaman kepada banyak orang beriman untuk menikmati cinta Allah dan sekaligus melahirkannya dalam tindakan. Makna tindakan di sini menjadi penting, sebab menurut William Johnston:

"Jangan mengira bahwa masuk dalam misteri Kristus itu berarti lari dari dunia [...] bahwa misteri Kristus itu terpusat pada salib-Nya. Artinya, ini terpusat pada orang miskin, orang sakit, orang malang, orang tersingkir, dipenjara, orang meninggal, dan semua orang menderita, sebab dengan mereka Yesus mempersatukan diri" (Johnston, 1987: 25).

Pengalaman mistik Kristiani adalah masuk ke dalam dunia.

Pengalaman tentang mistik cinta terhadap Allah bukanlah monopoli kaum laki-laki. Mistik cinta pun dijumpai dalam pengalaman banyak perempuan. Para mistikus perempuan ini mewakili sebuah pengalaman keintiman dengan Tuhan melalui kespontanitasan, belas kasih, kebebasan, dan tidak hierarkis (Dickens, 2009: 7). Intimitas cinta itu antara lain terlihat pada mistikus perempuan Muslim terkenal, Rabi'a Al-Adawiyah (713-801), yang dalam sepanjang hidupnya berusaha mencari kesatuan dengan Yang Ilahi dan berdampak dalam kehidupan di dunia (Smith, 1997: 19). Kedudukan perempuan menurut Margaret Smith juga sangat khas. Mengapa?

\footnotetext{
"Tujuan para biarawati dan wanita-wanita asketis yang paling utama dan pertama adalah untuk mencapai kesucian hidup. Yaitu dengan cara memberikan pelayanan kemanusiaan. Misalnya dengan mengabdikan diri mereka kepada pemeliharaan kaum yang lemah dan miskin ditambah lagi dengan kegiatan meditasi dan doa" (Smith, 2007: 57).
}

Kaum perempuan menghayati imannya kepada Yesus sebagai pengalaman diperhatikan, ditemani, dan diberikan hidup yang bermakna serta terlibat dalam karya kasih dan keadilan yang diprihatinkan-Nya. Ia dialami sebagai yang memberikan kepada para perempuan kesempatan untuk menemukan diri sendiri, berkembang dan berjalan bersama mencari Allah dalam perjuangan kasih dan keadilan. Ia melayani bagaikan ibu yang mengembangkan dan memberdayakan hidup.

Selain Santa Faustina Kowalska (1905-1938) — rasul agung kerahiman-yang disebut langsung oleh Paus Fransiskus dalam bulla-nya (Fransiscus, 2016: 71; Leks, 2016: 8), Julian dari Norwich (1343-1416) adalah contoh lain. Banyak masyarakat awam yang mendapat akses untuk berteologi dan menghayati Allah secara intim dan mistis, maka seorang Julian dari Norwich, misalnya, adalah seorang mistikus perempuan yang dipengaruhi oleh legasi kekuatan pembebasan Meister Eckhart (1260-1328) (Almirzanah, 93: 118). Julian yang juga seorang biarawati asal Inggris lalu merefleksikan kekuatan pembebasan dalam hidup beriman itu melalui karyanya "Showings" 
tentang pengalaman mistik cinta Allah. Gambaran Julian tentang cinta Allah itu sangat jelas dalam gambaran Yesus sebagai ibu (Dickens, 2009: 142-145). Katanya, "Dalam pengenalan dan hikmat, kita menjadi sempurna dalam keperempuanan kita, pemulihan kita dan keselamatan kita, karena Kristus adalah Ibu kita, saudara dan penyelamat."9 Lebih jauh Julian menjelaskan pengalaman cinta Allah di dalam Yesus yang menghidupkan. Katanya:

\footnotetext{
"Demikian Yesus adalah ibu kita yang sejati karena kita diciptakan-Nya. Ia pun ibu kita yang sejati dalam kasih karunia karena Ia mengambil darah-daging seorang makhluk seperti kita. Segala karya kasih dan indah seorang ibu terdapat pada-Nya, di dalam Dia kita berkemauan baik, utuh dan selamat sentosa, baik secara naluri dan karena anugerah, karena Ia membagi kebaikan-Nya kepada kita". ${ }^{10}$
}

Julian-lah yang juga mendorong agar setiap orang melihat dirinya sendiri dan orang lain sebagai manusia yang sudah ditebus. Kita adalah orang baik dan kita adalah orang suci. Hal ini mengingatkan kita pada konsep Eckhart tentang setiap orang adalah "pribadi berharga" (royal person) (Fox, 1980: 47), yang dalam kata-kata apresiatif Julian bahwa "semua akan berjalan baik, semua akan berjalan baik, segalanya akan berjalan baik" (Johnston, 2001: 199, 231). Pemikiran yang menempatkan manusia demikian terhormat ini adalah sesuatu yang langka di zaman Julian dan para mistikus seperti Eckhart. Penghormatan akan hidup manusia inilah sisi pembebasan dalam spiritualitas perempuan Julian dan itu diwujudkan dalam tindakan belarasa terhadap yang kecil dan miskin dari setiap orang yang mencintai dan dicintai Allah.

Di era modern ini, pengalaman mistik cinta dan kerahiman Bunda Teresa dari Kalkuta (19101997) juga menjadi pengalaman perempuan akan Allah yang bersifat pribadi namun berdampak sosial bagi perubahan yang diharapkan (Dyckman dan Carroll, 1981: 82). Bunda Teresa yang di-beatifikasi pada 19 Oktober 2003 oleh Paus Yohanes Paulus II dan pada 4 September 2016 dikanonisasi oleh Bapa Fransiscus menjadi seorang Santa Teresa dikenal luas sebagai "Ibu Kaum Miskin" (Marwanto, 2016: 8-9). Pengalaman mistiknya menunjukkan kepada kita bahwa jalan sederhana (a simple path) menuju kekudusan adalah doa dan cinta kasih kepada Allah melalui cinta kasih kepada saudara dan saudari kita (Vardey, 1997: xxxi-xli). Pada waktu kita berdoa, hati kita dimurnikan dan kita dapat melihat Allah dalam diri saudara dan saudari kita yang berkekurangan. Bila kita mengasihi mereka, kita masuk ke dalam hati Allah dan dipenuhi dengan kasih, damai, dan sukacita-Nya, sekarang dan selama-lamanya. Santa Teresa gemar mengutip sebuah ayat dalam Matius 25:40, di mana Tuhan berkata kepada kita, apa pun yang kamu lakukan untuk orang yang paling kecil dari antara saudara-saudari-Ku, itu kamu lakukan untuk Aku (Misionaris Cinta Kasih, 2004: 8-9, 13, 21-22; Sudiarja, 2015: 67-86 [83]). Kutipan dari Pengadilan Terakhir tersebut menjadi panggilan setiap kita untuk menemukan Allah pada yang lain, yang benar-benar berbeda, 
seraya mengakui bahwa Allah seringkali mengambil rute lain untuk mengenalkan diri-Nya melalui kaum papa miskin, menderita, dan teraniaya.

Dari sini jelas bahwa penggambaran mistik cinta sebagai tujuan dan puncak hidup manusia sesungguhnya tidak memberi kesan bahwa orang harus mengejar pengalaman mistik sebagai puncak terakhirnya. Lalu orang belum merasa tenang sebelum sampai pada pengalaman puncak itu. Padahal pengalaman akan relasi dan cinta Allah, yang menginti dan menentukan dalam hidup beriman Kristiani, terus berlanjut kepada tindakan mencinta (Dyckman dan Carroll, 1981: 83). Bahkan dalam rangka cinta kepada Allah, kedudukan manusia selalu darurat, sementara Allah selalu bisa ditunda. Dalam refleksinya, Eckhart pernah mengatakan, "Ketika aku sedang bermeditasi dan orang miskin minta padaku semangkok sup, hal yang harus aku lakukan adalah meninggalkan meditasi dan memerhatikan orang miskin tadi" (Almirzanah, 2009: 197). Tuhan bisa ditunda, tetapi manusia tidak bisa ditunda. Berhadapan dengan individu situasinya adalah senantiasa darurat, dibutuhkan penanganan yang segera pula. Jadi jelaslah bahwa cinta kepada Tuhan tidak diperlawankan dengan cinta kepada sesama. Malah cinta kepada Tuhan semakin nyata dalam cinta kepada sesama.

Dalam hal ini kita terbantu dengan gambaran Aloysius Pieris yang menggeser paradigma puncak kehidupan beriman. Dalam sejarah tradisi Kristen memang kita temukan pandangan yang menempatkan kontemplasi mistik sebagai puncak. Kemudian menyusul paradigma lain yang menempatkan liturgi dan sakramen sebagai puncak (Olla, 2010: 161-162). Pieris mengemukakan paradigma alternatif, love is action, cinta kasih adalah tindakan. ${ }^{11}$ Tindakan cinta yang nyata adalah solidaritas dengan kaum miskin dan korban eksploitasi. Dalam titik ini para mistikus perempuan, seperti: Rabi'a Al-Adawiyah, Julian dari Norwich, dan Santa Teresa dari Kalkuta, sejalan dengan Pieris dalam memberi wujud cinta Allah melalui tindakan kasih dan keadilan kepada sesama yang paling lemah, miskin, dan menderita.

\section{SPIRITUALITAS CALVIN MELALUI GAMBARAN GEREJA SEBAGAI IBU}

Alasan muncul dan lajunya gerakan reformasi Gereja sangatlah kompleks. Ada bermacam-macam faktor yang ikut memainkan peranan. Keadaan Gereja Roma waktu itu sangat memprihatinkan, terutama hierarki Gereja dan secara khusus kuria Roma, merupakan hal yang sudah cukup lama direaksi oleh bermacam-macam kritik dan usaha perbaikan (Almirzanah, 2009: 78-86; Kristiyanto, 2003: 81-85). Krisis teologi skolastik mengakibatkan formalisme kosong. Muncul pula kesadaran 
politis di negara-negara Eropa melawan kekuasaan Paus yang dianggap merintangi bagi terbentuknya pemerintahan lokal. Belum lagi keadaan sosial dan ekonomi di negara-negara Eropa, khususnya di Jerman, membuat bangsawan rendahan dan para petani haus akan perbaikan hidup.

Di kota Worms terdapat monumen Martin Luther yang bertuliskan: Hier steh' ich, ich kann nicht anders. Sementara itu di perpustakaan Universitas Heidelberg dijumpai arsip berupa tulisan tangan dengan kalimat yang berbunyi: Ich kann nicht anders; hier steh' ich; Gott helfe mir. Arti tulisan-tulisan itu adalah "Di sini aku berdiri, aku tidak bisa lain, semoga Allah menolong aku”. Tulisan ini adalah sikap Martin Luther mengenai pandangan-pandangannya yang sudah beredar (Stauffer, 1967: 97). Bahwa hati nuraniku tertangkap oleh firman Allah, aku tidak dapat dan tidak mau menarik apa pun, karena adalah berbahaya dan tidak mungkin aku melawan suara hati. Semoga Allah menolong aku. Pengalaman iman (pertobatan) Martin Luther ini diolahnya sebagai pengalaman religius personal yang peka akan suara hatinya yang kuat laksana batu karang menyangkut kebenaran iman yang dialaminya. Dorongan untuk tidak membungkam suara hati dihayati Luther sebagai suara Allah sendiri.

Ketika Lutheranisme mulai pudar, John Calvin muncul dan meneruskan reformasi. Dalam sejarah Gereja, John Calvin adalah orang pertama dari zaman modern dan reformis generasi kedua, yang berusia 26 tahun lebih muda dari pada Martin Luther. Sementara Martin Luther dapat dikatakan sebagai orang terakhir dari abad pertengahan. John Calvin memulai reformasi atas gereja di Perancis, yang merupakan negara monarki absolut. Perancis dengan semboyannya un roi, une loi, une foi, (satu raja-satu hukum-satu iman) membuat gerakan reformasi tidak mendapat ruang sama sekali untuk berkembang (Elwood, 2002: 13; Batlajery, 2011: 132).

Gagasan teologi Calvin tentang gereja sebagai ibu mengusung pergulatan Calvin sendiri pada tema keesaan gereja (Batlajery dalam Yewangoe [ed.], 2004: 297-320 [304]). Gereja adalah ibu dari sekalian orang percaya, maka tidaklah patut untuk melepaskan diri dari padanya, sebab keselamatan hanya dapat diberikan olehnya. Gagasan ini antara lain dilatarbelakangi oleh pengalaman Calvin sendiri di Perancis yang sangat keras menentang reformasi. Tumbuhnya reformasi karena perpecahan nyata di dalam tubuh gereja memberi pelajaran berharga bagi Calvin untuk kembali ke gagasan tentang kerahiman ibu yang seharusnya menjadi hidup dari gereja itu sendiri, jantung dari Injil dan kriteria menentukan bagi kredibilitas gereja. Karena itu Calvin begitu serius dengan keesaan gereja dan menolak segala kecenderungan ke arah separatisme. Separatisme menurutnya adalah pekerjaan setan (Calvin, 2006: IV, 1025).

Sementara itu, teologi Calvin tentang gereja dibangun dari teologinya tentang manusia. Dan manusia yang dimaksud Calvin pun pertama-tama bukan individu melainkan dalam persekutuan 
atau bermakna sosial. Kata Calvin, "Manusia menurut kodratnya adalah makhluk sosial; naluri alamiah mendorongnya untuk mengasuh dan memelihara persekutuan." ${ }^{12}$ Dari sini jelas bahwa bagi Calvin, dimensi sosial dari manusia ini seharusnya membawanya menjadi pengasuh dan pemelihara dari kehidupan. Salah satu nilai kebajikan dari hidup adalah bahwa manusia di dalam persekutuannya adalah manusia yang diterima dalam keberadaan dan perbedaannya. Karena tidak ada seorang pun yang ditolak, maka Calvin sangat giat dalam mempertahankan kesatuan di dalam masyarakat termasuk di dalam gereja.

Dalam Institutio versi bahasa Inggris, Institutes of the Christian Religion, Calvin mengatakan bahwa karena Allah disebut Bapa, maka "gereja harus disebut ibu" dan kita semua adalah anakanaknya. ${ }^{13}$ Selanjutnya menurut Calvin:

\footnotetext{
“Akan tetapi, karena maksud kami sekarang ialah membicarakan Gereja yang kelihatan, maka marilah kita belajar dari nama Ibu, betapa besar manfaatnya, bahkan betapa perlunya pengetahuan tentang Gereja itu bagi kita. Tidak ada jalan masuk ke dalam kehidupan kalau kita tidak dikandung di dalam rahimnya, dilahirkan olehnya, disusuinya, dan akhirnya dilindungi dan dibimbingnya, sampai kita menanggalkan daging yang mesti mati ini dan menjadi sama dengan malaikat. Kelemahan kita tidak mengizinkan kita untuk meninggalkan sekolah sampai kita menyelesaikan seluruh hidup kita sebagai murid-murid.”14
}

Konsep Calvin tentang gereja sebagai ibu dan gereja sebagai sekolah haruslah ditempatkan dalam konteks keesaan gereja. Calvin sangat menekankan keesaan gereja dalam eklesiologinya. Bicara gereja berarti bicara keesaannya. Kata Calvin, "Gereja itu dinamakan Katolik atau Am, sebab tidak mungkin didapati dua atau tiga gereja tanpa membuat Kristus terbagi; suatu hal yang mustahil." $" 15$

Bagi Calvin jelas bahwa yang pertama-tama harus dipahami tentang gereja adalah kekatolikannya, bukan kesuciannya atau apostolisitasnya (bdk. Batlajery, 2011: 135). Hanya ada satu gereja di muka bumi ini, satu tubuh Kristus di mana Kristus adalah kepala. Di dalam Dia semua orang pilihan dipersatukan dan bertumbuh bersama-sama ke arah satu tubuh. Di dalam Dia sebagai kepala, semua orang pilihan bersatu-padu dan tidak ada satu anggota pun yang tertolak di dalamnya. Kelak, ide kesatuan dengan Kristus ini dikembangkan dalam pengertian mistik, yang masih akan kita lihat diuraian berikut.

Dasar keesaan gereja adalah keesaan Allah sendiri. Kata Calvin, "Bahwa Allah esa, bahwa Kristus adalah Allah dan Anak Allah, bahwa keselamatan kita terletak dalam rahmat Allah dan sebagainya." ${ }^{16}$ Karena itu Calvin memang tidak menghendaki adanya perpecahan dalam gereja. Baginya hanya ada satu gereja saja di muka bumi di mana Kristus adalah kepalanya. Selain menurut Calvin bahwa "Gereja itu dinamakan Katolik atau Am, sebab tidak mungkin didapati dua atau tiga gereja tanpa membuat Kristus terbagi”, maka "setiap orang pilihan dipersatukan dengan Kristus 
(bdk. Ef. 1:22-23) mempunyai satu Kepala, mereka juga tumbuh bersama sebagai satu tubuh."17 Di sinilah kita menemukan terminologi "unio cum Christo" (union with Christ) sebagai kesatuan mistik dengan Kristus yang kuat dalam spiritualitas Calvin (van den Brink dan Smits, 2015: 325347 [332 c.k. 23]). Dalam banyak literatur jelas ditegaskan bahwa kesatuan dengan Yang Ilahi merupakan bahasa yang khas dalam teologi mistik (Knitter, 2002: 112-113, 125; Rice, 1991: 26; Johnston, 1987: 25). Gagasan tentang kesatuan mistik (unio mystica) tentang relasi dengan Kristus dan sesama manusia (keduanya tidak terpisah), dipelajari Calvin dari teolog dan mistikus Bernard dari Clairvaux, yang sangat memengaruhinya (Elwood, 2002: 79-81; Richard, 1974: 79-81). Ini artinya bahwa kerinduan Calvin pada kesatuan dengan Yang Ilahi, selain berakar pada pengalaman luka akibat perpecahan gereja di masanya, juga mengakar pada karya pengutusan Kristus yang menyatukan semua di dalam-Nya.

Tema kerahiman dalam spiritualitas Calvin yang bertolak dari keesaan gereja ini paling jelas ketika dihubungkan dengan peran gereja sebagai ibu kita yang mendidik anak-anaknya dalam kesukacitaan. Kata Calvin, "Gereja adalah ibu kita [...] untuk mendidik anak-anak gerejanya kesukacitaan sampai bertemu di dalam tempat perteduhan." ${ }^{18}$ Kerahiman seorang ibu yang mendidik anak-anaknya menempatkan gereja sebagai rumah tempat tinggal yang aman dan nyaman untuk bertumbuh bersama.

Calvin mengingatkan bahwa persekutuan di dalam gereja yang penuh kerahiman itu tidak boleh diputuskan begitu saja, termasuk ketika terjadi kesalahan. Calvin mencontohkannya demikian. Sekalipun kesalahan itu berupa penyelenggaraan pengajaran maupun pelaksanaan sakramen-sakramen, semua orang dipertahankan sebagai anggota gereja. Kata Calvin:

\footnotetext{
“Asas ini begitu jauh jangkauannya sehingga persekutuan yang demikian sekali-kali tidak boleh kita tolak selama mempertahankan hal-hal tersebut, sekalipun amat banyak kesalahannya dalam hal-hal lain. Bahkan penyelenggaraan pengajaran maupun sakramen-sakramen itu boleh jadi dimasuki kesalahan. Tetapi, tak perlu kenyataan itu menjauhkan kita dari persekutuan dengannya, sebab pokok-pokok ajaran yang benar tidak semuanya sama wujudnya."19
}

Guna memperjelas maksudnya, yaitu kerahiman dalam rangka kesatuan hidup gereja, Calvin membedakan antara hal-hal yang mutlak dan perlu diketahui (yakni dua inti hidup gereja yang benar: firman dan sakramen), ${ }^{20}$ dan hal-hal yang tidak mutlak. Sehingga, kata Calvin, "Perbedaan pendapat mengenai hal-hal yang tidak mutlak itu seyogyanya tidak menjadi sebab perpecahan di antara kaum Kristen." ${ }^{21}$ Saya mencoba menerapkan apa yang Calvin maksudkan ini pada persoalan yang hangat hari-hari ini. Bagaimana kalau hal-hal yang tidak mutlak (seperti dimaksud Calvin) itu termasuk isu seputar LGBT (Lesbian, Gay, Biseksual, dan Transeksual)? Dengan memakai perspektif Calvin isu seperti ini akan ditanggapi dalam dua sikap pastoral, yaitu: (1) 
tidak boleh memutuskan atau memisahkan atau mengeluarkan seseorang dari persekutuan dengan gereja; dan (2) tidak boleh juga menjadi sebab perpecahan di antara kaum Kristen. Pandangan dan sikap ini menjadi langkah pastoral gereja yang dalam teologi Calvin didasarkan pada gagasan gereja sebagai ibu. Kerahiman ibu menerima setiap kita menjadi anak-anaknya. Kerahiman gereja sebagai ibu juga membuat tidak seorang pun (apa pun keadaan dan latar belakang hidupnya) tertolak dari dalamnya. Di atas semua itu, kesatuan mistik dengan Kristus (unio cum Christo) melahirkan penghayatan akan cinta Allah yang tidak mengenal batas. Itulah kerahiman Allah di dalam spiritualitas Calvin.

\title{
SPIRITUALITAS KERAHIMAN DAN KETERLIBATAN SOSIAL
}

William Johnston memberikan gambaran mengenai kesatuan antara anugerah panggilan hidup mistik dan rasa kesetiakawanan, rasa bersatu satu sama lain, dengan lingkungan dan dengan seluruh alam raya. Kutipan dari Johnston berikut ini kiranya dapat memberi gambaran tentang spiritualitas hidup mistik Kristen.

\begin{abstract}
"Mistikus sejati tidak pernah dapat melarikan diri dari dunia. Ia harus berempati dengan penderitaan dan kesedihan yang merupakan warisan bersama umat manusia. Bahkan mistikus yang hidup menyendiri yang tinggal di gunung atau gurun harus tetap berhubungan dengan dunia - mencintai dunia, menderita dengan dunia, menghadapi kejahatan dunia.
\end{abstract}

Dan para mistikus aktif yang hidup di tengah hiruk pikuk dunia masuk ke alam diam batin seperti yang dialami oleh mereka yang hidup di gurun. Mereka mengalami api batin dan cahaya batin; mereka mengalami kobaran cinta yang menyala, yang membuat ada mereka menjadi ada yang mencinta. Nah, api batin itu mendorong merekabukan lagi ke rimba belantara (kendati mereka mungkin memang hidup untuk beberapa waktu lamanya di rimba raya), melainkan ke pasar yang berjejalan dan ke kota batin. Kobaran cinta yang menyala mendorong mereka ikut mengadakan pawai damai, berdemonstrasi di jalanan, mengutuk struktur yang menindas, menghadapi raja-raja dan penguasa, pergi ke penjara dan mati di sana. Seperti mistikus di gurun, mereka mengalami malam gelap yang menyedihkan dan mencapai pencerahan mendalam. Mistikus di gurun sepi dan mistikus di kota sibuk sama-sama mengikuti Dia yang mengosongkan diri-Nya dan mengambil rupa hamba serta dianugerahi nama yang melebihi segala nama" (Johnston, 2001: 364-365).

Pertanyaannya: bagaimana dengan Calvin? Untuk menggali spiritualitas Calvin yang tidak terpisah dengan kesetiakawanan dan keterlibatan sosial, maka rasanya perlu mendudukkan ulang, apakah benar bahwa Calvin sendiri memang mengajarkan tentang kerusakan total manusia (human depravity)? Atau, jangan-jangan teologi tentang manusia yang sudah rusak total (human depravity) itu disumbang oleh teologi Calvinis (Ortodoks) seperti tercermin dalam Pengakuan Iman Belanda? 
Menurut saya ajaran kerusakan total manusia (human depravity) bukanlah berasal dari Calvin sendiri tetapi dari Pengakuan Iman Belanda yang dipengaruhi oleh teologi Calvinis Ortodoks..22 Rasanya Gerrit Singgih benar saat mengatakan bahwa Calvinisme (pen.: bukan Calvin), yang menurutnya tidak mendorong perbaikan masyarakat karena tekanan yang terlalu besar pada human depravity (Singgih, 2009: 205-207). Sementara Calvin sendiri tidak. Ia masih mengapresiasi "akal" (reason) sebagai bagian yang kodrati yang dianugerahkan Allah dan tidak ikut rusak total dalam peristiwa kejatuhan manusia ke dalam dosa. Dengan akalnya manusia masih tetap dapat membedakan hal baik dan buruk beserta keinginan untuk mencari kebenaran. Secara lengkap Calvin mengatakan:

\begin{abstract}
“Akal, yang membuat orang sanggup membeda-bedakan yang baik dengan yang jahat, sanggup mengerti dan menilai, merupakan pemberian yang kodrati. Jadi, tidak mungkin akal itu dihapuskan sama sekali, tetapi sebagiannya dilemahkan, sebagian lagi dicemarkan, sedemikian rupa hingga yang tampak hanyalah puing kehancuran [...] Dalam kodrat manusia yang betapapun bejat dan merosotnya masih juga ada beberapa percik api yang menunjukkan bahwa ia makhluk yang berakal [...] Jika kita menyalahkan akal manusia sebagai sama sekali buta, dengan pengertian bahwa akal itu tak sanggup lagi untuk memahami sesuatu apa pun, maka pendirian itu bertentangan dengan firman Allah dan juga bertentangan dengan pengalaman akal sehat. Karena kita melihat bahwa di dalam kodrat manusia ditanamkan semacam keinginan untuk mencari kebenaran." ${ }^{23}$
\end{abstract}

Jika menurut Calvin akal tidak mengalami kerusakan, karena merupakan bagian dari apa yang dianugerahkan Allah, maka Calvin sepertinya juga memaksudkan akal budi seperti yang Lonergan maksud sebagai daya dorong menuju transendensi dan keautentikan diri (Lonergan, 1975: 111; Johnston, 2001: 254). Karena akal adalah anugerah, maka akal juga sarana cinta ilahi yang hidup dalam semua manusia dan memberi daya dorong untuk menyatu dengan sang ilahi termasuk dalam tindakan nyata.

Akal yang dianugerahkan dan menjadi sarana cinta ilahi dalam tindakan-tindakan nyata itu paling jelas dalam ajaran Calvin tentang peranan warga gereja yang menurut Calvin tidak boleh hanya mengikuti kehendak orang lain, termasuk pemimpin agama. Kata Calvin, "Demi pembangunan rohani sesuai dengan bakat masing-masing menjadi tugas setiap anggota Gereja, asal saja dijalankan dengan pantas dan tertib." ${ }^{24}$ Besarnya kedudukan dan peran warga gereja ini dapat disejajarkan dengan salah satu tema dalam khotbah Meister Eckhart tentang “orang terhormat" (royal person) (Fox, 1980: 47). Yang dimaksud dengan royal person adalah setiap manusia tanpa terkecuali. Tidak ada sedikit pun yang kurang dalam diri manusia karena diciptakan mulia. Dan oleh siapa pun dan dalam keadaan apa pun kemuliaan manusia tidak boleh dikurangi. Karena itulah Eckhart dan Calvin di zamannya masing-masing membantu banyak orang menemukan rasa dimanusiakan kembali. Penegasan inilah yang mendorong banyak orang 
di zaman Eckhart dan Calvin untuk menjadi mandiri dan bebas dalam mengeskpresikan harga dirinya dan keberagamaannya karena keyakinan pada dirinya sebagai ciptaan yang mulia. Dari situ pulalah angin reformasi dihembuskan dan diberi makna sebagai emansipasi sosial.

Perasaan dimanusiakan itu diperjelas Calvin melalui apa yang disebutnya sensus divinitatis dan semen religionis, yaitu kesadaran yang kuat akan kehadiran Allah atau perasaan keagamaan yang terdapat dalam manusia. Kesadaran atau perasaan inilah yang membimbing setiap orang melakukan kegiatan keagamaan dan berbagai kebajikan etis sebagai bagian dari "kelahiran kembali" (regeneratio) (Singgih, 2005: 268). Tentang ini Calvin mengatakan, "Kehendak bebas tidak menyanggupkan manusia untuk berbuat baik, kecuali kalau ia dibantu oleh anugerah Allah, yaitu [...] melalui kelahiran kembali." 25 Dan yang paling penting bahwa dalam "kelahiran kembali" tidak ada dikotomi iman dan perbuatan. Dari sinilah Calvin menyumbang sebuah pengertian khas tentang Protestantisme sebagai pengalaman manusia yang fundamental dan langsung di hadapan Allah sebagai paradoks antara, di satu pihak penentuan diri dengan ketegangan yang tak terselesaikan, dan di lain pihak belas kasih Allah yang menganugerahkan kepenuhan manusiawi dalam belarasa dan solidaritas dengan mewujudkan keadilan dan dengan disertai rahmat Allah untuk melaksanakan itu.

Spiritualitas kerahiman yang terlibat pada keresahan dunia jelas terlihat dari syair puisi yang ditulis oleh Marie Claire Barth Frommel dalam bukunya. Puisi ini diinspirasi oleh etika Calvin tentang syukur kepada Tuhan yang telah bertindak memberikan hidup dan keselamatan bagi umat manusia (Frommel, 2006: 306-307):

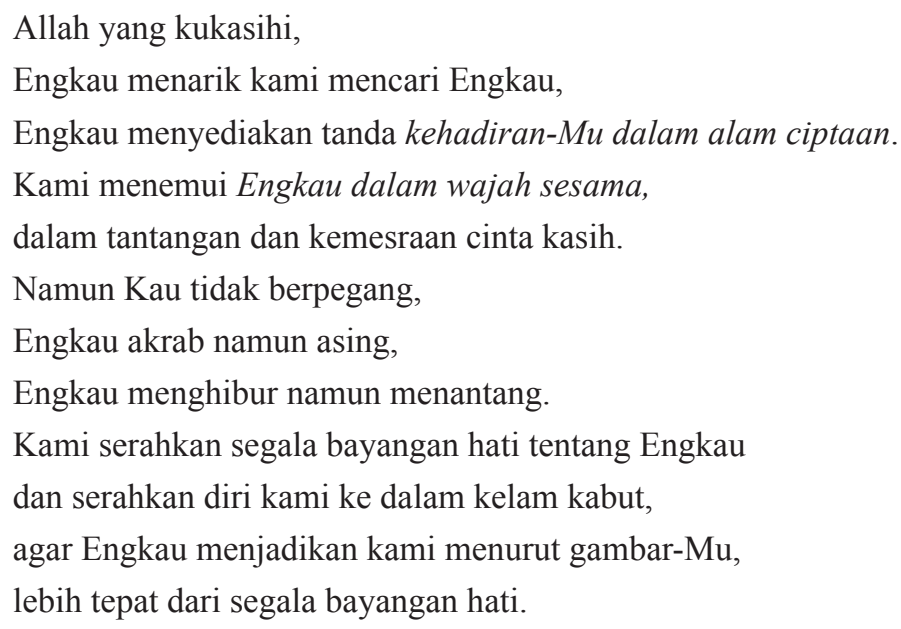

Puisi di atas menggemakan kepedulian Calvin dan gerakan Protestan secara umum, yakni belas kasih dan kepedulian terhadap dunia dengan mewujudkan keadilan serta pembelaan terhadap yang tidak berdaya, dan dengan disertai rahmat Allah untuk melaksanakan itu. Di sini 
peranan anugerah menjadi penting. Spiritualitas Calvin menempatkan anugerah sebagai daya ilahi yang menyanggupkan manusia untuk berbuat baik. Anugerah Allah adalah anugerah istimewa yang memampukan setiap orang keluar kepada dunia dan mengubah dunia (Calvin, 2000: 64; 2006: II, 262). Antara anugerah Allah dan panggilan untuk memperjuangkan keadilan tidak ada pertentangan. Bahkan kesatuan dengan Kristus (unio cum Christo) mendapat perwujudan paling radikal dalam hidup adil bersama yang lain.

Ihwal dari kebaikan, belas kasih, dan kepedulian itu adalah dengan menjadikan dunia ini theatrum gloriae Dei (de Jonge, 2011: 386), menjadikan dunia sebagai panggung kemuliaan Allah. Sebagai panggung, maka dunia ini adalah tempat di mana cinta kasih Allah dipertemukan atau diteruskan dalam cinta kepada sesama dan ciptaan lainnya. Mengenal Allah (knowledge) bagi Calvin adalah mengenal diri sendiri, termasuk mengenal itu dicapai melalui mediasi dari para wakil Allah yang dijumpai pada sesama yang menderita. Karena itu mengenal Allah tidak terpisah dari panggilan pada "kesalehan" (pietas). Kesalehan (pietas) itu sendiri erat dengan makna antropologis yang perwujudannya tidak hanya dalam kerajinan beribadah dan berdoa tetapi utamanya keaktifan dalam berbuat kebajikan demi pengudusan hidup di dunia ini (Jones, 1995: 150; Richard, 1974: 90, 178-180). Inilah "kesadaran diri”" (self conciousness) yang dicapai justru dengan keluar dari diri, mengosongkan diri, dan tidak lekat (letting go) pada segala sesuatu yang dapat mengalihkan pandangan kita dari mencintai Allah (Fox, 1980: 210).

Cita-cita hidup Calvin adalah demi kemuliaan Allah yang lebih besar, Ad Maiorem Dei Gloriam. Semboyan ini langsung mengingatkan kita pada semboyan sama yang juga dipakai oleh Ignatius Loyola, pendiri Serikat Yesus (Richard, 1974: 141-143; Faber, 2009: 662-672). Memang John Calvin (1509-1564) dan Ignatius Loyola (1491-1556) hidup dan menjalani studi di Paris pada periode yang hampir sama. Untuk memuliakan Allah itu Calvin dan Ignatius mohon rahmat agar mengenal Yesus, mencintai dan mengikuti-Nya lebih dekat. Latihan Rohani Ignatius mengandung kontemplasi-kontemplasi mengenai misteri hidup Yesus yang diambil dari Alkitab, yakni dari empat Injil dalam Perjanjian Baru. Ignatius dari Loyola dan John Calvin menggambarkan ideal orang beriman sebagai cotemplativus in actione, yaitu orang yang menghidupi pengalaman kontemplatif dalam tindakan sehari-hari, orang yang berusaha mencari dan menemukan Allah dalam pengalaman sehari-hari. Keduanya menghayati Roh Kudus hadir bekerja dalam dunia nyata dan memanggil manusia untuk terlibat dan keresahan dunia.

Dalam ajarannya tentang Roh Kudus, Calvin pertama-tama menentang deisme, yang mengatakan bahwa setelah menciptakan dunia ini, Allah membiarkan dunia ini berjalan sendiri 
(van den End, 2001: xii, 3). Menurut Calvin, dalam karyanya Institutio, karya Roh tetap bekerja sebagai creator (pencipta), conservator (pemelihara), dan gubernator (pengendali) (Calvin, 2006: I, 197). Pemeliharaan Allah melalui Roh-Nya tetap berlangsung terus-menerus. Dan kehadiranNya paling nyata lewat mediasi manusia yang menghadirkan kemuliaan Allah.

Di Asia, upaya menjadikan dunia sebagai panggung kemuliaan Allah diberi bentuk oleh seorang teolog yang terinspirasi pada Calvin, Choan-Seng Song. Ia mengatakan bahwa upaya memuliakan Allah berarti peka pada problem kemanusiaan yang tumpah ruah di Asia. Menurut Song, manusia yang bermasalah (problematic humanity) adalah pusat perhatian teologi. Lebih jauh Song mengatakan:

"Allah bukanlah problem dari teologi. Adalah kemanusiaan yang merupakan problem dari teologi. Problematika kemanusiaan adalah subjek dari teologi. Urusan utama teologi adalah melihat bagaimana Allah membuat problematika kemanusian menjadi selesai. Inilah alasan bahwa teo-logi harus menjadi antropo-logi. Logos dari theos adalah logos dari anthropos." ${ }^{26}$

Song ingin memperlihatkan kesetiaannya pada teologi Calvin yang mengatakan bahwa Allah tidak bisa dipelajari lepas dari manusia. Allah ditemukan dalam hubungan dengan manusia. Mengapa, karena kata Song, "Allah, mencurahkan perhatikan kepada seluruh dunia, seluruh kemanusiaan-yaitu kesejahteraan dan keselamatan." ${ }^{27}$ Melalui cinta kepada sesama dan ciptaan lainnya, kerahiman Allah dihayati sebagai belas kasihan yang memanggil kepada tindakan nyata.

Masih ada satu hal lagi yang penting didiskusikan di sini. Bahwa dalam rangka perayaan 500 tahun reformasi tahun 2017 mendatang, pemikiran Calvin menjadi salah satu yang perlu terus dipikirkan ulang. Calvin, misalnya, sangat terkesan dengan teks 1 Petrus 2:9 tentang ide umat terpilih. Teks ini mengilhami Calvin mengembangkan ide umat terpilih yang terdiri dari imamimam dan diujicobakan di kota Geneva (namun gagal). Calvinisme ortodoks lalu mempertajam ide umat terpilih itu secara eksklusif untuk menunjukkan perbedaan antara umat Kristiani dengan nonKristiani. ${ }^{28}$ Dari sinilah Calvinisme ortodoks mengembangkan teologi eksklusif yang menempatkan umat Kristiani sebagai pewaris tunggal keselamatan sementara umat lainnya ditolak. Memang di zamannya Calvin tidak menyarankan perang terhadap Turki yang Islami, tetapi sikapnya tetap tidak berubah memandang Islam sebagai bertentangan dengan Injil, khususnya pada moralitasnya yang rendahan. Baginya upaya orang untuk mencari titik temu antara Islam dan Kristen adalah salah (Hartono, 2006: 13-21 [18]). Dari penjelasan di atas jelas bahwa sejarah penafsiran atas teks 1 Petrus 2:9 sarat dengan ideologi umat terpilih yang eksklusif, dan tak jarang berkelindan dengan dominasi kultural bahkan eropasentris. 
Dengan menggunakan tafsir postkolonial, Gerrit Singgih, misalnya, kritis dengan tafsiran kolonial yang telah tertanam kuat berupa dukungan terhadap ekspansi, diskriminasi, dan sikap kebencian terhadap yang lain. Untuk konteks pluralisme religius-kultural yang menjadi tantangan kita di Indonesia, pemahaman Calvin perlu ditransformasi melalui memperluas ide Calvin tentang umat terpilih menjadi umat terpilih yang melayani dunia (election not for honour but for service) (Singgih, 2000: 136, 140). Pelayanan kepada dunia sekaligus keterbukaan pada dunia melalui sikap belajar dari yang lain. Dengan melayani dunia umat Kristiani terhubung dengan komunitaskomunitas lain untuk sama-sama mengusahakan hidup yang lebih baik dan adil. Dari upaya terusmenerus membaca ulang pemikiran Calvin inilah spiritualitas kerahiman beroleh maknanya untuk merawat keragaman sebagai rahmat ilahi.

Yang terakhir, pengalaman akan kerahiman Allah di masa kini ditantang oleh keprihatinan kontekstual dalam gambaran sebuah patung perunggu karya seniman Kanada, Timothy P. Schmalz, Homeless Jesus. Sejak Maret 2016 patung ini dipasang di salah satu sudut Vatikan untuk merefleksikan pesan Injil di tengah gelombang pengungsi zaman ini. Para pengungsi itu antara lain saudara-saudari Muslim yang menderita akibat konflik berkepanjangan di berbagai belahan dunia, khususnya Timur Tengah. Di Indonesia tidak sulit mengidentifikasikannya dengan pengungsi Muslim Rohingya asal Myanmar yang didiskriminasi di negaranya dan lari ke Aceh. Dengan mengambil inspirasi dari kisah Pengadilan Terakhir (Mat. 25:40), deskripsi awal tentang patung pengungsi ini berkata:

"Kita tidak akan pernah mengenali wajahnya. Ia mungkin saja salah satu orang yang berkelana di jalanan dan tidur tanpa atap di waktu malam. Akan tetapi, ia tidak lain daripada Kristus. Bekas luka paku salib terlihat di kakinya" (Awangga, 2016: 38-40).

Pengungsi tidak hanya "menantang" umat Kristiani untuk mengenali Kristus dalam diri orang asing dan membutuhkan, tetapi juga menyambutnya dalam kasih dan damai sekalipun mereka berbeda agama atau keyakinan. Demi kerahiman Allah yang tanpa batas, kita terpanggil turut menyelamatkan kaum marginal, para pengungsi, orang yang dianggap remeh, dan mereka yang tidak diinginkan (un-will people) dengan tanpa alasan selain karena cinta kepada Allah. Itulah praksis kerahiman Allah. 


\section{PENUTUP}

Sampai di sini saya telah mencoba menjawab pertanyaan, adakah tema kerahiman di dalam tradisi Protestan yang dapat dijadikan pijakan mengembangkan teologi spiritualitas Protestan? Saya juga sudah membuktikan bahwa spiritualitas kerahiman adalah khas dalam teologi Calvin. Spiritualitas kerahiman mempunyai dasar dalam tradisi sistematis Protestan, yaitu pada pemikiran Calvin. Itu juga berarti bahwa tema kerahiman dapat dipakai sebagai salah satu titik temu agama-agama tentang belas kasihan Allah. Kesatuan dengan Allah bukanlah keterpisah-pisahan, melainkan dihayati semakin radikal dalam pengalaman keterlibatan konkret.

Dari penelusuran atas spiritualitas kerahiman Calvin, kita menemukan beberapa pemikiran khas yang dapat dipakai untuk menghayati spiritualitas kita di hari ini. Pertama, kerahiman bagi Calvin pertama-tama adalah kesatuan dengan Kristus (unio cum Christo). Inilah kesatuan mistik (unio mystica) dengan Kristus yang Calvin hayati dan mengubah hidupnya menjadi manusia baru, yaitu manusia yang mencintai Allah secara total. Pengalaman intim dengan Allah ini bagi Calvin adalah keterbukaan pada dunia dengan terpanggil ikut dalam pengudusan dunia lewat tindakan nyata. Kedua, kerahiman yang Calvin pahami juga berarti mencinta seperti Allah mencintai. Cinta Allah adalah cinta yang tidak mengenal batas. Inilah pusat dari seluruh misi Allah kepada dunia ini. Ketiga, kerahiman juga berarti merawat keesaan gereja, di mana tidak ada seorang pun yang boleh ditolak untuk berada di dalam gereja. Semua orang diterima dan semua orang dicintai oleh Allah. Semua dimasukkan dalam kerahiman Allah yang tanpa batas. Keempat, kerahiman bagi Calvin adalah upaya mengenal Allah melalui mengenal manusia. Di sini Calvin terbuka pada mediasi orang lain untuk dapat tiba pada pengetahuan tentang Allah. Homeless Jesus adalah salah satu tantangan bagi praksis kerahiman Allah. Dalam kerahiman Allah, panggilan setiap orang adalah mewujudkan "kesalehan" (pietas) melalui keterlibatan aktif pada penegakan keadilan dan hidup baik bersama yang lain.

\section{Catatan}

1 Teks Inggris: "So it is clear that there were efforts by Calvin to save Servetus. He had worked for the redemption of Servetus [...] He was not involved in the process of making the decision, and his position in Geneva at the time was weak. On the contrary, when decision has been made for 'cruelly burning' he tried to ask for communication of the sentence as shown in a letter he wrote to Farel [...] And of course, we also agree that this case is a case of violence. But we cannot say that the idea of cruelly burning was Calvin's idea" (lih. Batlajery, 2014: 17-27 [26]).

${ }^{2}$ Saya menggunakan buku versi bahasa Inggris Institutes of the Christian Religion karya John Calvin terjemahan Ford Lewis Battles dan dieditori oleh John T. McNeill edisi tahun 2006 (lihat c.k. 1). Dan sebagai pembanding dalam 
bahasa Indonesia saya menggunakan terjemahan dalam buku Yohanes Calvin, Institutio: Pengajaran Agama Kristen, terjemahan Winarsih, J.S. Aritonang, Arifin, dan Th. van den End (2000: 234).

${ }^{3}$ Kata subita menunjuk pertobatan yang berlangsung seumur hidup (lih. Balke dalam Batlajery dan van den End [eds.], 2014: 13; Battles (ed.), 2012: 76, c.k. 257).

${ }^{4}$ Kata Bernard J.F. Lonergan: "All love is self-surrender, but being in love with God is being in love without limits or qualifications or conditions or reservations" (lih. Lonergan, 1975: 105-106).

5 Bernard J.F. Lonergan mengatakan: "I have conceived being in love with God as an ultimate fulfilment of man's capacity for self-transcendence” (lih. Lonergan, 1975: 111; Johnston, 2001: 84, 254).

${ }^{6}$ Calvin mengatakan: "I call 'piety' that reverence joined with love of God which the knowledge of his benefits induces” (lih. Calvin, 2006: I, 41; 2000: 11).

${ }^{7}$ Kata Calvin: "There is within the human mind, and indeed by natural instinct, an awareness of divinity. This we take to be beyond controversy. To prevent anyone from taking refuge in the pretense of ignorance, God himself has implanted in all men a certain understanding of his divine majesty. Ever renewing its memory, he repeatedly sheds fresh drops" (lih. Calvin, 2006: I, 43 [ditulis dalam bentuk lain: Divinitatis Sensum, lihat c.k. 2]; 2000: 13).

${ }^{8}$ Ruffing mengatakan: "The Christian tradition of love mysticism is rooted in the biblical tradition of a personal God revealed by the self-donating love of Jesus" (lih. Ruffing, 2000: 100).

9 Kata Julian: "In knowledge and wisdom we have our perfection, as regards our sensuality, our restoration and our salvation, for he is our Mother, brother and savior" (lih. Julian of Norwich, 1978: 293; lih. juga Frommel, 2006: 179, c.k. 25).

${ }^{10}$ Julian mengatakan: "And so Jesus is our true Mother in nature by our first creation, and he is our true Mother in grace by his taking our created nature. All the lovely works and all the sweet loving offices of beloved motherhood are appropriated to the second person, for in him we have this godly will, whole and safe forever, both in nature and in grace, from his own goodness proper to him" (lih. Julian of Norwich, 1978: 296; Frommel, 2006: 180, c.k. 25).

${ }^{11}$ Kata Pieris: "Action is the expression of Love that sums up God's own inner Trinitarian life as well as God's liberative intervention in our personal and social history through God's partnership with the poor" (lih. Pieris, 1999: 64-66).

${ }^{12}$ Kata Calvin: "Since man is by nature a social animal, he tends through natural instinct to foster and preserve society" (lih. Calvin, 2006: II, 272; 2000: 67; van den End dalam Batlajery dan van den End, 2014: 139).

${ }^{13}$ Kata Calvin: "The Church may also be Mother" (lih. Calvin, 2006: 1012).

${ }^{14} \mathrm{Kata}$ Calvin: "But because it is now our intention to discuss the visible church, let us learn even from the simple title 'mother' how useful, indeed how necessary, it is that we should know her. For there is no other way to enter into life unless this mothes conceive us in her womb, give us birth, nourish us at her breast, and lastly, unless she keep us under her care and guidance until, putting off mortal flesh, we become like the angels (Mattew 22:30). Our weakness does not allow us to be dismissed from her school until we have been pupils all our lives" (lih. Calvin, 2006: IV, 1016; 2000: 229).

${ }^{15}$ Kata Calvin: "The Church is called 'catholic' or 'universal', because there could not be two or three churches unless Christ be torn asunder (bdk. 1 Kor. 1:13); which cannot happen” (lih. Calvin, 2006: IV, 1014; 2000: 227).

${ }^{16}$ Kata Calvin: "God is one; Christ is God and the Son of God; our salvation rests in God's mercy; and the like" (lih. Calvin, 2006: IV, 1026; 2000: 234).

${ }^{17}$ Kata Calvin: "Hence the Church is called Catholic or Universal" [...] dan "But all the elect are so united in Christ (bdk. Efesus 1:22-23) that as they are dependent on one Head, they also grow together into one body" (lih. Calvin, 2006: IV, 1014; 2000: 227).

${ }^{18}$ Kata Calvin: "The Church is our mother [...] For this education of the Church her children enjoined to meet in the sanctuary" (lih. Calvin, 1989: 279). Penjelasan mengenai kutipan dalam Institutio terjemahan Henry Beveridge 
sayang tidak disebutkan lagi dalam Institutio hasil editan John T. McNeill, sehingga saya tetap mengikuti terjemahan Beveridge (lih. Calvin, 2006: IV, 1014-1016).

${ }^{19}$ Kata Calvin: "The principle extends to the point that we must not reject it so long as it retains them, even if it otherwise swarms with many faults. What is more, some fault may creep into the administration of either doctrine or sacraments, but this ought not to estrange us from communion with the church. For not all the articles of true doctrine are of the same sort" (lih. Calvin, 2006: IV, 1025-1026; 2000: 234).

${ }^{20} \mathrm{Hal}$ yang pokok itu termasuk kata Calvin: "God is one; Christ is God and the Son of God; our salvation rests in God's mercy; and the like" ("Allah adalah esa, bahwa Kristus adalah Allah dan Anak Allah, bahwa keselamatan kita terletak dalam rahmat Allah dan sebagainya') (lih. Calvin, 2006: IV, 1026; 2000: 234).

${ }^{21}$ Kata Calvin: "A difference of opinion over these nonessential matters should in no wise be the basis of schism among Christians" (lih. Calvin, 2006: IV, 1026; 2000: 234).

22 Pengakuan Iman Belanda, Pasal 14 diberi judul kecil: "Penciptaan dan kejatuhan manusia, dan ketidakmampuan manusia untuk berbuat baik." Pada uraian PIB ada beberapa keterangan yang dapat mengindikasikan kerusakan total yang dimaksud: "Ia telah merusak segenap kodratnya", "serta bejat dalam segala jalannya", "ia kehilangan semua karunia gemilang... sehingga tiada yang tinggal", "karena seluruh terang yang ada di dalam diri kita telah berubah menjadi kegelapan" (lih. van den End, 2011: 30; lih. juga van den Brink dan Smits, 2015: 332).

${ }^{23}$ Calvin mengatakan: "Since reason, therefore, by which man distinguishes between good and evil, and by which he understands and judges, is a natural gift, it could not be completely wiped out; but it was partly weakened and partly corrupted, so that its misshapen ruins appear [...] in man's perverted and degenerated nature some sparks still gleam. These show him to be a rational being [...] When we so condemm human understanding for its perpetual blindness as to leave it no perception of any object whatever, we not only go against God's Word, but also run counter to the experience of common sense. For we see implanted in human nature some sort of desire to search out the truth [...]" (lih. Calvin, 2006: II, 270-271; 2000: 66-67).

${ }^{24}$ Kata Calvin: "From this it is clear that every member of the church is charged with the responsibility of public edification according to the measure of his grace, provided he perform it decently and in order" (lih. Calvin, 2006: IV, 1026; 2000: 235).

${ }^{25}$ Kata Calvin: "Free will is not sufficient to enable man to do good works, unless he be helped by grace, indeed by special grace, which only the elect receive through regeneration" (lih. Calvin, 2006: II, 262; 2000: 64).

${ }^{26}$ Kata Song: "God is not a theological problem. It is we human beings who are the problem for theology. Problematic humanity is the subject of theology. The business of theology is to see how God makes this problematic humanity less problematic. For this reason theo-logy must be anthropo-logy. The logos of theos is the logos of anthropos" (lih. Song, 1984: 37).

${ }^{27}$ Kata Song: "God, concerned about the whole world, the whole of humanity-its welfare and salvation" (lih. Song, 1984: 39).

${ }^{28}$ Di sini dicontohkan pemikiran Karl Barth (lih. Forward, 2001: 74).

\section{DAFTAR PUSTAKA}

Almirzanah, Syafa'atun. 2009. When Mystic Masters Meet: Paradigma Baru dalam Relasi Umat Kristiani-Muslim, Jakarta: Gramedia. 
Awangga, Surya. 2016. "Beriman Jujur via Homeless Jesus", Rohani, No. 09, Tahun Ke-63, September.

Balke, W. 2014. "Calvin dan Calvinisme", dalam Agustinus M.L. Batlajery dan Th. van den End, Ecclesia Reformata semper Reformanda: Dua Belas Tulisan Mengenai Calvin dan Calvinisme, Jakarta: BPK Gunung Mulia.

Batlajery, Agustinus M.L. 2004. "Keesaan Gereja Menurut Calvin dan Maknanya bagi Gerejagereja di Indonesia”, dalam A.A. Yewangoe (ed.), Kontekstualisasi Pemikiran Dogmatika di Indonesia: Buku Penghormatan 70 Tahun Prof. Dr. Sularso Sopater, Jakarta: BPK Gunung Mulia dan STT Jakarta.

. 2011. “Keesaan Gereja Menurut Calvin dalam Institutio 1536”, Studia, Vol. 11, No. 1, Maret.

. 2014. "Calvin and Servetus: A Case of Violence and Calvin's Involvement", Sola Experientia, Vol. 2, No. 1, April.

Battles, Ford Lewis. 1996. Interpreting John Calvin, Grand Rapids: Beker Book. (ed.). 2012. Kesalehan John Calvin: Kumpulan Prosa, Puisi, dan Kidung Rohaninya, Surabaya: Momentum.

Calvin, John. 1957. On the Christian Faith, ed. John T. McNeill, New York: A Liberal Arts Press Book.

. 1989. Institutes of the Christian Religion, terj. Henry Beveridge, Grand Rapids, Michigan: Eerdmans Publishing Company.

.2000. Institutio: Pengajaran Agama Kristen, terj. Winarsih, J.S. Aritonang, Arifin, dan Th. van den End, Jakarta: BPK Gunung Mulia.

. 2006. Institutes of the Christian Religion, ed. John T. McNeill, Louisville, Kentucky: Westminster John Knox Press.

De Jonge, Christiaan. 2011. Apa itu Calvinisme?, Jakarta: BPK Gunung Mulia.

Dickens, Andrea Janelle. 2009. The Female Mystic: Great Women Thinkers of the Middle Ages, New York: I.B. Tauris.

Dyckman, Katherine Marie, dan L. Patrick Carroll. 1981. Inviting the Mystic Supporting the Prophet: An Introduction to Spiritual Direction, New York: Paulist Press.

Elwood, Christopher. 2002. Calvin for Armchair Theologians, Louisville, London: Westminster John Knox Press. 
Faber, Eva-Maria. 2009. “Johannes Calvin und Ignatius von Loyola”, Stimmen Derzeit, Heft 10, Oktober.

Forward, Martin. 2001. Inter-religious Dialogue: A Short Introduction, Oxford: One World.

Fox, Matthew. 1980. Breakthrough: Meister Eckhart'd Creation Spirituality in New Translation, New York: Image Books.

Fransiscus, Paus. 2016. Bulla Pemakluman Tahun Yubileum Kerahiman Ilahi Luar Biasa, Yogyakarta: Kanisius.

Frommel, Marie Claire Barth. 2006. Hati Allah bagaikan Hati seorang Ibu: Pengantar Teologi Feminis, Jakarta: BPK Gunung Mulia.

Hartono, Chris. 1997. "Spiritualitas Gerakan Reformasi: Tradisi-tradisi Lutheran, Calvinis dan Anabaptis", Penuntun, Vol. 3, No. 12, Juli.

. 2006. "Spiritualitas Calvinis", Gema Teologi, Vol. 30, No. 2, Oktober.

Johnston, William. 1987. Mistik Kristiani: Sang Rusa Terluka, terj. A. Soenarja, Yogyakarta: Kanisius. . 2001. Teologi Mistik: Ilmu Cinta, Yogyakarta: Kanisius.

Jones, Serena. 1995. Calvin and the Rhetoric of Piety, Louisville, Kentucky: Westminster John Knox Press.

Julian of Norwich. 1978. Showings, terj. Edmund Colledge dan James Walsh, New York: Paulist Press.

Knitter, Paul F. 2002. Introduction Theologies of Religions, New York: Orbis Books.

Kristiyanto, Edy. 2003. Visi Historis Komprehensif: Sebuah Pengantar, Yogyakarta: Kanisius.

Leks, Stefan. 2016. Kompendium Devosi Kerahiman Allah, Yogyakarta: Kanisius.

Lonergan, Bernard J.F. 1975. Method in Theology, London: Darton, Longman \& Todd.

Marwanto, Yanuari. 2016. "Dari Comberan Menuju Kekudusan”, Hidup, Santa Kaum Papa dari Kalkuta, Tahun ke-70, 28 Agustus.

Misionaris Cinta Kasih. 2004. Mari, Jadilah Terangku: Merayakan Beatifikasi Ibu Teresa dari Kalkuta, Yogyakarta: Kanisius.

Olla, Paulinus Yan. 2010. Teologi Spiritual: Pengantar pada Teologi Spiritual, Tema-tema dan Strukturalisasi Pengajarannya, Yogyakarta: Kanisius.

Pabubung, Michael Reskianto. 2016. "Kerahiman Allah dalam Doa”, Rohani, No. 06, Th. Ke-63, Juni. 
Pieris, Aloysius. 1999. God's Reign for God's Poor. A Return to the Jesus Formula: A Critical Evaluation of Contemporary Reformulations of the Mission Manifesto in Roman Catholic Theology and in Recent Jesuit Documents, Gonawila-Kelaniya: Tulana Research Centre.

Rice, Howard L. 1991. Reformed Spirituality: An Introduction for Believers, Louisville, Kentucky: Westminster John Knox Press.

Richard, Lucien Joseph. 1974. The Spirituality of John Calvin, Atlanta, Georgia: John Knox Press. Ruffing, Janet K. 2000. Spiritual Direction: Beyond the Beginning, New York: Paulist Press.

Sheldrake, Philip. 1998. Spirituality and Theology: Christian Living and the Doctrine of God, New York: Orbis Books.

Singgih, E.G. 2000. Reformasi dan Transformasi Pelayanan Gereja Menyongsong Abad Ke-21, Yogyakarta: Kanisius. .2000. Iman dan Politik dalam Era Reformasi di Indonesia, Jakarta: BPK Gunung Mulia. . 2005. Mengantisipasi Masa Depan: Berteologi dalam Konteks di Awal Milenium III, Jakarta: BPK Gunung Mulia . 2009. Menguak Isolasi, Menjalin Relasi: Teologi Kristen dan Tantangan Dunia Postmodern, Jakarta: BPK Gunung Mulia.

Smith, Margaret. 1997. Rabi'a: The Life \& Work Of Rabi'a And Other Women Mystics In Islam, Oxford: Oneworld.

. 2007. Mistisisme Islam \& Kristen: Sejarah Awal dan Perkembangannya, terj. Amroeni Drajat, Jakarta: Gaya Media Pratama.

Soetapa, Djaka. 2013. "Teologi Kerahiman”, dalam John C. Simon, Teologi Progresif: Studi Komparatif-Orienting Islam-Kristen di Indonesia (1999-2010), Yogyakarta: Kanisius.

Song, Choan-Seng. 1984. Tell Us Our Name: Story Theology From an Asian Perspective, New York: Orbis Books.

Stauffer, Richard. 1967. Luther As Seen by Catholics, London: Lutter Worth Press.

Sudiarja, A. 2015. Lima Kuntum Bunga Gereja, Yogyakarta: Kanisius.

Van den Brink, Gijsbert, dan Johan Smits. 2015. "The Reformed Stance: Distinctive Commitments and Concerns", Journal of Reformed Theology, No. 9.

Van den End, Th. 2001. Harta dalam Bejana: Sejarah Gereja Ringkas, Jakarta: BPK Gunung Mulia. 
. 2011. Enam Belas Dokumen Dasar Calvinisme, Jakarta: BPK Gunung Mulia.

. 2014. "Beberapa Catatan Pembimbing pada Tata Gereja Calvinis", dalam Agustinus

M.L. Batlajery dan Th. van den End, Ecclesia Reformata Semper Reformanda: Dua Belas Tulisan Mengenai Calvin dan Calvinisme, Jakarta: BPK Gunung Mulia.

Vardey, Lucida. 1997. Ibu Teresa: A Simple Path (Jalan Sederhana), Jakarta: BPK Gunung Mulia. 